\title{
PENGARUH KEPRIBADIAN MEREK TERHADAP KOMITMEN DAN KEPERCAYAAN MEREK, SERTA DAMPAKNYA TERHADAP LOYALITAS MEREK
}

\author{
Made Dwi Utari ${ }^{(1)}$ \\ I Ketut Rahyuda ${ }^{(2)}$ \\ I Gusti Ayu Ketut Giantari ${ }^{(3)}$ \\ (1),(2),(3)Fakultas Ekonomi dan Bisnis Universitas Udayana, Bali, Indonesia \\ email: utari.0329@hotmail.com
}

\begin{abstract}
ABSTRAK
Perilaku konsumsi masyarakat yang dipengaruhi oleh kesadarannya pada kerusakan lingkungan menjadi latar belakang dilakukannya penelitian ini. Penelitian ini bertujuan untuk menjelaskan pengaruh kepribadian merek terhadap kepercayaan dan komitmen merek, yang kemudian mengakibatkan loyalitas merek salah satu produk kosmetik dan perawatan diri organik di Kota Denpasar. Data dikumpulkan dengan metode survei menggunakan instrumen kuesioner. Teknik pengambilan sampel adalah purposive sampling berjumlah 150 responden, kemudian data dianalisis dengan SEM (Structural Equation Modelling). Hasil penelitian adalah kepribadian merek berpengaruh positif signifikan terhadap komitmen dan kepercayaan merek. Begitu juga dengan komitmen merek dan kepercayaan merek, ditemukan berpengaruh positif signifikan terhadap loyalitas merek. Implikasi teoritis penelitian ini adalah memperkaya konsep kepribadian merek yang ditemukan oleh Aaker(1997). Implikasi praktis bagi perusahaan produk ini adalah memperkuat dimensi kehandalan yang merepresentasikan kepribadian merek, indikator setia mengkonsumsi produk dalam waktu yang lama yang merepresentasikan komitmen merek, dan indikator konsistensi kualitas yang merepresentasikan kepercayaan merek dalam rangka meningkatkan loyalitas merek.
\end{abstract}

Kata Kunci: kepribadian merek, loyalitas merek

\begin{abstract}
Consumer behavior that's influenced by their awareness toward environment damage becomes the background of this research. This research aims to explain the influence of brand personality on brand trust and brand commitment, and its impact on brand loyalty of organic cosmetic and personal care product in Denpasar. Survey was conducted to get 150 valid respondents defined by purposive sampling using questionnaire. Collected data is analyzed with SEM (Structural Equation Modelling). This research found that brand personality influence brand commitment and brand trust significantly positive. So do, brand commitment and brand trust are significantly positive affecting brand loyalty. This research theoretically implicates the development of brand personality concept developed by Aaker (1997). Meanwhile, practical implications for this product are to improve the performance of competence dimension proved reflecting brand personality, long term usage indicator proved reflecting brand commitment, and consistent quality indicator proved reflecting brand trust in order to increase brand loyalty.
\end{abstract}

Keywords: brand personality, brand loyalty

\section{PENDAHULUAN}

Kampanye mengenai kelestarian lingkungan saat ini dapat ditemukan dimana-mana. Masyarakat mulai merasakan dampak dari kerusakan lingkungan, dan mulai berhati-hati dalam aktivitasnya. Kesadaran masyarakat ini kemudian mempengaruhi preferensi, sikap, dan perilaku mereka sehari-hari, termasuk perilakunya dalam mengkonsumsi produk dan jasa (Paramita dan Kerti Yasa, 2015; Rizwan et al., 2014; Waskito, 2015). Perusakan lingkungan dominan dengan zat-zat kimia dan bahan-bahan yang tidak dapat lebur secara alami, sehingga kini masyarakat lebih memilih produk dan jasa yang menggunakan bahan-bahan yang ramah lingkungan, atau yang kita kenal dengan bahan-bahan organik.

Perkembangan trend organik tidak hanya terjadi pada produk-produk pangan, namun juga pada kosmetik dan produk perawatan diri, seperti: hand body lotion, shampoo, facial foam, parfum, dan sebagainya, yang notabenenya merupakan produk yang cenderung menggunakan bahan kimia pada proses pembuatannya. Hal ini bertolak belakang dengan kebiasaan organik yang kini tumbuh di masyarakat, sehingga jika tidak disiasati dengan baik, produk-produk seperti ini akan kehilangan konsumennya. 
Produk kosmetik dan perawatan diri organik Amenanggapi kesadaran masyarakat terhadap produk organik dengan melakukan langkah strategi, yaitu: menunjukkan komitmennya terhadap pelestarian lingkungan, menawarkan produk dengan bahan-bahan alami, ramah lingkungan, dan no animal testing. Prinsip dasar ramah lingkungan yang dimiliki produk kosmetik dan perawatan diri organiklahir dari ide-ide untuk menggunakan kembali, mengisi ulang dan mendaur ulang apa yang mereka bisa pakai kembali, besarnya peranan bisnis sebagai penentu arah perubahan tercermin dengan mengarahkan bisnis untuk mengukur keberhasilan dari tiga pilar pendukungnya yaitu: people, product, dan planet (thebodyshop.co.id/aboutus).

Produk kosmetik dan perawatan diri merupakan produk yang unik karena selain mampu memenuhi kebutuhan mendasar akan kecantikan, juga sebagai sarana konsumen untuk memperjelas identitas dirinya di masyarakat. Keunikan produk kosmetik dan perawatan diri ini membuat konsep kepribadian merek berperan penting dalam penentuan strategi pemasarannya, karena kepribadian merek membantu konsumen untuk mengekspresikan dirinya melalui merek yang dipilihnya.Setiap individu memiliki persepsinya masing-masing terhadap suatu merek, sehingga pemasar akan menyesuaikan kepribadian merek apa yang akan dikembangkan dengan karakteristik segmen pasar yang ditargetkan.

Penelitian ini mengimplementasi kerangka latar belakang tersebut pada merek produk kosmetik dan perawatan diri organik Ayang telah memiliki kesan organik yang kuat pada konsumennya. Pra-riset telah dilakukan pada 12 orang pelanggan merek produk kosmetik dan perawatan diri organik Ayang loyal untuk memperkuat landasan dilakukannya penelitian ini. Pra-riset ini dilakukan dengan metode wawancara dan survei dengan menjawab contoh kuesioner penelitian. Pra-riset tersebut menghasilkan 92\% responden loyal pada merek produk kosmetik dan perawatan diri organik A, $100 \%$ responden menyatakan dirinya percaya dan berkomitmen terhadap merek produk kosmetik dan perawatan diri organik A. Namun, hanya $75 \%$ responden mengaku memiliki kesan bahwa merek produk kosmetik dan perawatan diri organik A tersebut memiliki kepribadian merek tertentu, dan hanya $75 \%$ pula yang mengungkapkan kepribadian merek produk kosmetik dan perawatan diri organik Atersebut mampu menunjukkan kepribadian dirinya.

Hasil pra-riset tersebut menunjukkan bahwa persentase responden yang loyal terhadap merek A tidak sebesar yang percaya dan berkomitmen terhadapnya. Hal ini juga sejalan dengan rendahnya persentase responden yang telah memiliki persepsi kepribadian merek produk kosmetik dan perawatan diri organik A. Hal ini juga didukung oleh data dari Top Brand Award (2016), yang menunjukkan hasil survei pada konsumen Indonesia mengenai merek perawatan pribadi berdasarkan pada tiga hal yaitu: top of mind awareness, penggunaan terakhir, dan keinginan menggunakan di masa depan.

Tabel 1 menunjukkan bahwa meskipun Merek A berhasil menempati posisi top brand pada dua katagori, persentase yang diperoleh merek A menurun dari tahun 2015 hingga 2016. Sementara, persentase merek B dari tahun 2015 hingga 2016 mengalami peningkatan, bahkan pada katagori body mistmerek B memperoleh 8,5\% pada tahun 2016 padahal sebelumnya tidak ternominasi pada tahun 2015. Jika hasil pra-riset dan data mengenai Top Brand Award dihubungkan, maka dapat diasumsikan bahwa merek A mengalami penurunan perolehan persentase top brand di benak konsumen kemungkinan diakibatkan oleh kurang kuatnya persepsi kepribadian merek merek A di benak konsumen, yang dapat menyebabkan kecenderungan berkurangnya konsumen yang loyal terhadap merek produk kosmetik dan perawatan diri organik A.

Merek memainkan peran penting dalam strategi pemasaran sebagian besar perusahaan karena dianggap sebagai sumber yang memungkinkan perusahaan memperoleh keunggulan dalam bersaing. Penelitian akademik saat ini berpusat pada proses mental yang dipicu oleh merek dalam pikiran pelanggan dibandingkan dengan aspek finansial demi

Tabel 1. Data Posisi Top Brand Award Merek Produk Kosmetik dan Perawatan Diri Organik A dan B

\begin{tabular}{ccccc}
\hline \multirow{2}{*}{ Merek } & \multicolumn{2}{c}{ Body Butter/Body Cream } & \multicolumn{2}{c}{ Body Mist } \\
\cline { 2 - 5 } & 2015 & 2016 & 2015 & 2016 \\
\hline A & $29,0 \%^{*}$ & $21,7 \%^{*}$ & $32,0 \%^{*}$ & $22,6 \% *$ \\
B & $7,5 \%$ & $10,5 \%$ & - & $8,5 \%$ \\
\hline
\end{tabular}

*dimana merek A adalah produk yang diteliti

Sumber: topbrand-award.com (2016) 
mengukur ekuitas merek (Guse, 2011). Kepribadian merek telah diteliti dan ditemukan signifikan sebagai penyebab dari preferensi (Aaker, 1997), kepercayaan (Ambroise et al., 2005; Louis dan Lombart, 2010; Sabrina dan Siti, 2011; Lee dan Kang, 2013; Ardestani dan Mahdi, 2015) dan loyalitas (Lee dan Kang, 2013; Yasin dan Amjad, 2013; Bouhlel et al., 2011; Listiani, 2013; Aydin et al., 2014) pada merek.

Kebanyakan penelitian mengenai produk perawatan diri organik hanya berfokus pada strategi pemasaran bukan pada perilaku konsumen di dalam industri tersebut (Kim dan Chung, 2011), sementara penelitian-penelitian mengenai merek telah mempelajari proses mental pelanggan, padahal menurut Kim dan Chung (2011) tanpa pemahaman yang mendalam pada perilaku konsumen terhadap katagori produk ini, akan sulit bagi produsen untuk membangun strategi pemasaran yang efektif. Kepribadian merek adalah serangkaian karakteristik manusia yang diasosiasikan dengan suatu merek (Aaker, 1997). Penelitian ini bermaksud untuk mengisi gap tersebut dengan membangun kerangka konsep yang menjelaskan proses mental yang terjadi pada pelanggan melalui varibel kepribadian merek, komitmen merek, kepercayaan merek, dan loyalitas merek, dan menerapkannya pada merek produk perawatan diri organik The Body Shop Indonesia.

Lee dan Kang (2013) melakukan penelitian dengan framework kepribadian merek Aaker (1997) yang dihubungkan dengan hubungan konsumenmerek dan sikap merek, yang kemudian menyebabkan keinginan membeli merek. Penelititian ini menjadikan hasil penelitian Lee dan Kang (2013) yang menyatakan bahwa kepribadian merek cenderung berpengaruh efektif dalam konsep jangka panjangsebagai latar belakang dilakukan penelitian ini.Konsep jangka panjang menurut Lee dan Kang (2013) adalah konsep yang terbentuk akibat hubungan yang berlangsung dalam waktu yang panjang, yang merupakan akumulasi dari beberapa variabel, misalnya: hubungan konsumen dan merek terbentuk akibat akumulasi dari sikap merek, asosiasi merek atau citra merek dalam jangka waktu tertentu.

Lada et al. (2014) dalam penelitiannya menguji hubungan kepribadian merek dengan loyalitas pelanggan yang dimoderasi oleh keterlibatan produk (product involvement), namun hasil yang diperoleh adalah hipotesis ini hanya diterima secara parsial. Penelitian Lin (2010) juga menemukan hal yang sama, yaitu kepribadian merek berpengaruh positif terhadap loyalitas merek namun hanya secara parsial. Hal ini membentuk celah untuk membangun kerangka penelitian dengan variabel lain sebagai variabel diantara kepribadian merek dengan loyalitas merek.

Penelitian terdahulu menemukan bahwa kepribadian merek berpengaruh signifikan terhadap komitmen merek (Sabrina dan Siti, 2011; Louis dan Lombart, 2010; Ardestani dan Mahdi, 2015), dan kepercayaan merek (Sabrina dan Siti, 2011; Bouhlel et al. 2011; Louis dan Lombart, 2010) namun penelitian Lee dan Kang (2013) menemukan bahwa beberapa dimensi kepribadian merek tidak berpengaruh signifikan terhadap komitmen dan kepercayaan merek.

Terdapat gap dalam penelitian-penelitian terdahulu mengenai hubungan komitmen merek dengan loyalitas merek, dan kepercayaan merek dengan loyalitas merek. Penelitian Sabrina dan Siti (2011); Lee et al. (2007); Demir et al. (2013); Turri et al. (2013); Berg (2013) menemukan bahwa komitmen merek berpengaruh signifikan terhadap loyalitas merek. Sementara penelitian Maheswari et al. (2014) menemukan bahwa komitemen merek tidak berpengaruh signifikan terhadap loyalitas merek. Begitu juga dengan pengaruh kepercayaan merek terhadap loyalitas merek. Penelitian Riana (2008); Ismail et al. (2012); Chandio et al. (2015) menemukan bahwa kepercayaan merek berpengaruh signifikan terhadap loyalitas merek, sementara Kuikka dan Laukkanen (2012) dan Shirin dan Puth (2011) menemukan bahwa kepercayaan merek tidak berpengaruh signifikan terhadap loyalitas merek.

Berdasarkan paparan fenomena dan paparan singkat mengenai kajian literatur di atas, maka penelitian ini merumuskan masalah, yaitu: bagaimanakah pengaruh kepribadian merek terhadap komitmen dan kepercayaan merek produk kosmetik dan perawatan diri organik A, serta dampak kedua variabel tersebut terhadap loyalitas pelanggan terhadap merek produk kosmetik dan perawatan diri organik A.

Berdasarkan rumusan masalah maka tujuan penelitian ini untuk menjelaskan pengaruh kepribadian merek terhadap komitmen dan kepercayaan merek produk organik dan perawatan diri organik A, serta dampaknya terhadap loyalitas pelanggan terhadap merek produk kosmetik dan perawatan diri organik A.

Kepribadian merek adalah serangkaian karakteristik manusia yang diasosiasikan dengan suatu merek (Aaker, 1997). Kepribadian merek secara khusus memiliki fungsi simbolik atau fungsi ekspresi diri yang kontras dengan fungsi utama dari dimensi citra merek lainnya. Kepribadian merek memungkinkan konsumen untuk mengekspresikan 
diri yang kemudian akan memengaruhi pilihan konsumen dalam mengkonsumsi produk maupun jasa. Aaker (1997) mengemukakan bahwa kepribadian merek memungkinkan merek bertindak sebagai seorang rekan, sebuah karakter, dan seorang individu. Sejalan dengan ini, Plummer (1985) mengemukakan bahwa kepribadian merek kemudian mampu memicu reaksi emosional dari konsumen, bahkan mampu menarik konsumen ke dalam hubungan jangka panjang dengan merek (Freling dan Forbes, 2005).

Aaker (1997) mengembangkan model lima dimensi kepribadian merek dengan faktor-faktor yang terdiri dari 1) Sincerity, 2) Excitement, 3) Competence, 4) Sophistication, dan 5) Ruggedness, yang didasarkan pada penelitian Goldberg (1992) yang menggambarkan garis besar sifat-sifat kepribadian manusia (yaitu: opennesss, conscientiousness, extraversion, agreeableness, dan neuroticsm). Tiga dari dimensi kepribadian merek dapat dihubungkan dengan dimensi kepribadian manusia, agreeableness (manusia) dan sincerity (merek) sama-sama memotret kehangatan dan penerimaan; extroversion (manusia) dan excitement (merek) keduanya mengandung konsep keramah-tamahan, energi, dan aktivitas; conscientiousness (manusia) dan competence (merek) keduanya merangkum tanggung jawab, kemandirian, dan keamanan (Aaker, 1997). Namun, dimensi sophistication dan dimensi ruggedness sedikit berbeda, dimana kedua dimensi tersebut lebih mengekspresikan sifat yang diinginkan dari pada sifatnya saat ini. Gambar 1 adalah framework kepribadian merek yang dikembangkan oleh Aaker (1997):
Komitmen konsumen pada dasarnya adalah keinginan dalam diri konsumen untuk mempertahankan hubungan yang berharga atau hubungan yang memberikan manfaat (valued relationship) untuknya. Hal ini menunjukkan bahwa, individu akan memiliki komitmen yang kuat atau tinggi jika ia menganggap hubungan tersebut penting baginya.Li et al. (2013) dalam artikelnya merangkum bahwa komitmen merek merepresentasikan hubungan antara merek dengan pelanggan, yang di demonstrasikan oleh sikap dan perilaku pelanggan, ditandai oleh kekuatan dan keawetan hubungan tersebut, dan penolakan terhadap perubahandalam hubungannya.

Kepercayaan adalah sejumlah variabel psikologis integritas (kejujuran pihak yang dipercaya dan kemampuan menepati janji), benevolence (perhatian dan motivasi yang dipercaya untuk bertindak sesuai dengan kepentingan yang mempercayai mereka), competency (kemampuan pihak yang dipercaya untuk melaksanakan kebutuhan yang mempercayai), dan konsistensi perilaku pihak yang dipercaya (Luarn dan Lin dalam Ferrinadewi, 2008:147). Dalam riset Costabile (Ferrinadewi, 2008:147) kepercayaan merek atau brand trust didefinisikan sebagai persepsi akan kehandalan dari sudut pandang konsumen didasarkan pada pengalaman atau terpenuhinya harapan konsumen terhadap kinerja produk tertentu (Alexander, 2014).

Kepercayaan merek memberikan beberapa keuntungan bagi produsen, yaitu: membuat pelanggan bergantung pada kemampuan merek dalam menjalankan fungsinya, terlibat dalam kredibilitas merek dalam penerimaan ekuitas merek, peran

\begin{tabular}{|c|c|c|c|c|}
\hline & & \multicolumn{2}{|c|}{$\begin{array}{c}\text { Brand Personality } \\
\text { (Kepribadian Merek) }\end{array}$} & \\
\hline $\begin{array}{c}\text { Sincerity } \\
\text { (Ketulusan) }\end{array}$ & $\begin{array}{l}\text { Excitement } \\
\text { (Kegembiraan) }\end{array}$ & $\begin{array}{l}\text { Competence } \\
\text { (Kehandalan) }\end{array}$ & $\begin{array}{l}\text { Sophistication } \\
\text { (Kecanggihan) }\end{array}$ & $\begin{array}{c}\text { Ruggedness } \\
\text { (Ketangguhan) }\end{array}$ \\
\hline $\begin{array}{l}\text { - Down-to-earth } \\
\text { (Sederhana) } \\
\text { - Honest } \\
\text { (Jujur) } \\
\text { - Wholesome } \\
\text { (Berman-faat) } \\
\text { - Cheerful } \\
\text { (Riang) }\end{array}$ & $\begin{array}{l}\text { - Daring } \\
\text { (Berani) } \\
\text { - Spirited } \\
\text { (Bersemangat) } \\
\text { - Imaginative } \\
\text { (Imajinatif) } \\
\text { - Up-to-date } \\
\text { (Mutakhir) }\end{array}$ & \begin{tabular}{|l} 
- Reliable \\
(Bisa \\
diandalkan) \\
- Intelligent \\
(Cerdas) \\
- Successful \\
(Sukses)
\end{tabular} & $\begin{array}{l}\text { - Upper class } \\
\text { (Kelas atas) } \\
\text { - Charming } \\
\text { (Mempesona) }\end{array}$ & \begin{tabular}{|l} 
- Outdoorsy \\
(Menyukai \\
tantangan) \\
- Tough \\
(Ulet)
\end{tabular} \\
\hline
\end{tabular}

Gambar 1. Framework Kepribadian Merek

Sumber: Aaker (1997) 
kepercayaan merek sebagai hal yang fundamental dalam membangun loyalitas merek, dan mungkin merupakan alat pemasaran hubungan paling kuat yang dimiliki perusahaan (Alhaddad, 2015).

Loyalitas pelanggan merupakan sesuatu dari pelanggan yang ingin dimenangkan oleh setiap produsen. Pelanggan yang loyal, selain melakukan pembelian, juga bersedia melakukan pengorbanan demi menjaga hubungannya dengan merek tertentu. Schiffman dan Kanuk (2008) memandang loyalitas konsumen sebagai hubungan antara sikap relatif individu terhadap entitas tertentu (merek, pelayanan toko, atau wiraniaga) dan perilaku berlangganan individu tersebut. Lebih lanjut, Schiffman dan Kanuk (2008) memaparkan sikap relatif konsumen terdiri dari dua dimensi: kekuatan sikap dan tingkat perbedaan sikap terhadap berbagai merek yang bersaing. Schiffman dan Kanuk (2008) merangkum dalam bukunya bahwa loyalitas terhadap merek timbul karena percobaan terhadap produk/jasa merek tertentu yang diperkuat oleh rasa puas terhadap percobaannya dengan produk/jasa merek tersebut dan kemudian dapat menimbulkan pembelian yang berulang kali. Namun sebaliknya, para peneliti kognitif lebih menekankan pada peran proses mental dalam pembangunan loyalitas merek (Schiffman dan Kanuk, 2008). Mereka yakin bahwa para konsumen terlibat dalam perilaku pemecahan masalah yang mendalam mencakup perbandingan merek dan sifat, yang berakhir pada preferensi merek yang kuat dan perilaku pembelian yang berulang-ulang (Schiffman dan Kanuk, 2008).

Pada Gambar 2 disajikan tentang kerangka konsep penelitian.

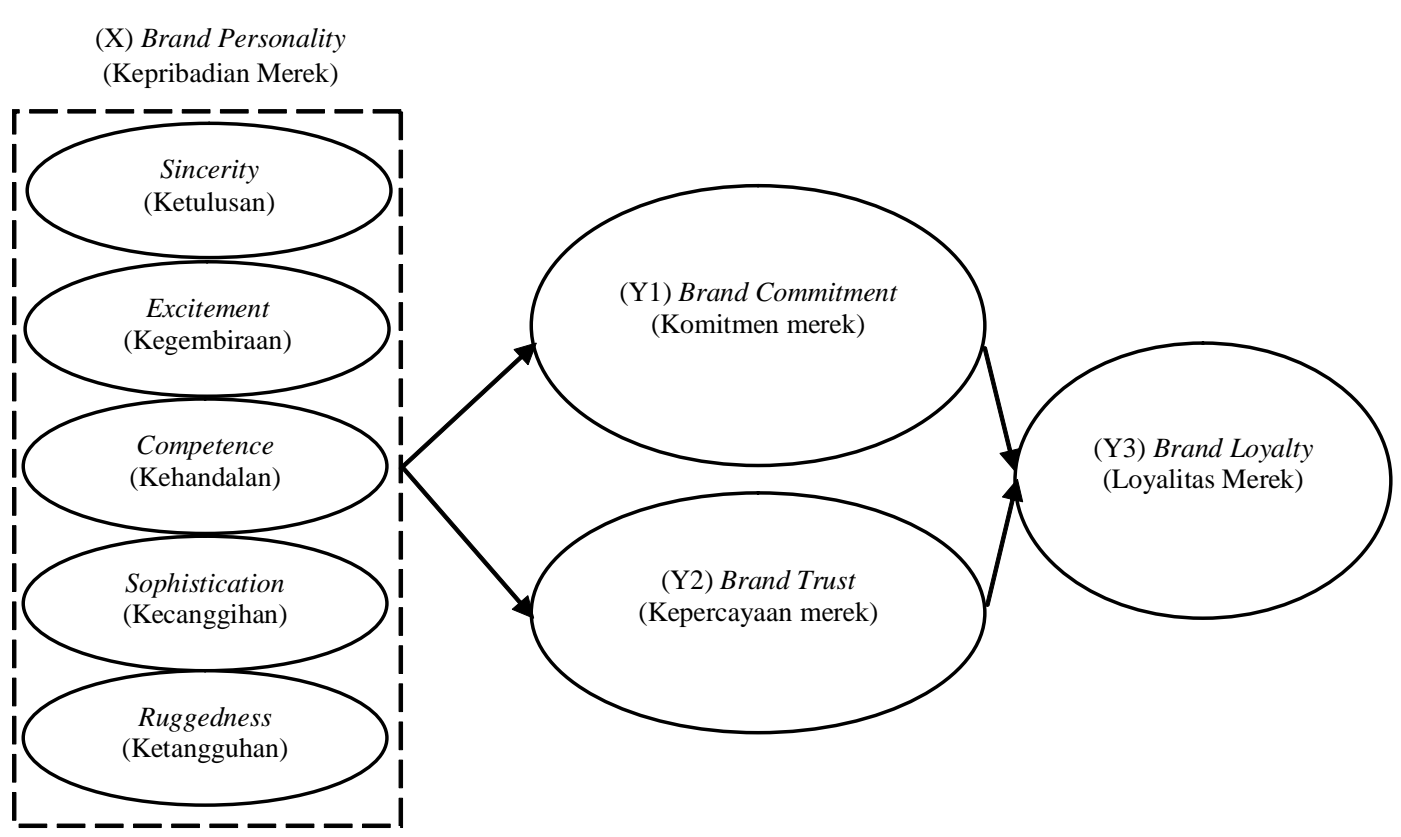

Gambar 2. Kerangka Konseptual Penelitian

Ambroise et al.(2005) menyatakan bahwa kepribadian merek yang lebih kuat dan stabil akan mengarahkan konsumen untuk menjaga komitmen mereka pada merek tersebut. Penelitian Sabrina dan Siti (2011) membuktikan bahwa kepribadian merek berpengaruh signifikan terhadap komitmen merek. Louis dan Lombart (2010) pada penelitiannya membuktikan hal yang sejalan, dimana kepribadian merek memiliki pengaruh yang signifikan terhadap komitmen merek, meskipun pengaruh tersebut berbeda antara dimensi kepribadian merek yang satu dengan yang lainnya. Ardestani dan Mahdi (2015) menemukan pada penelitiannya bahwa kepribadian merek berpengaruh signifikan terhadap komitmen merek. Penelitian Lee dan Kang (2013) menemukan bahwa dimensi kepribadian merek tidak secara signifikan berpengaruh terhadap hubungan konsumen-merek. Hubungan konsumen dengan merek yang dimaksudkan pada penelitian tersebut adalah komitmen dan kepercayaan merek.

$\mathrm{H}_{1}$ : Kepribadian merek berpengaruh positif signifikan terhadap komitmen merek.

Sabrina dan Siti (2011) pada penelitiannya membuktikan bahwa kepribadian merek berpengaruh signifikan terhadap kepercayaan merek, begitu pula dengan penelitian Bouhlel et al. (2011). Hal yang sama juga dibuktikan pada penelitian Louis dan 
Lombart (2010), dimana kepribadian merek memiliki pengaruh yang signifikan terhadap kepercayaan merek. Grohmann (2009) menyatakan bahwa kepribadian merek dapat menimbulkan respon positif terhadap kepercayaan konsumen terhadap merek tertentu.

Penelitian Bouhlel et al. (2011) menemukan beberapa dimensi kepribadian merek tidak signifikan mempengaruhi kepercayaan merek, sehingga pada penelitian ini dirumuskan hipotesis berikut:

$\mathrm{H}_{2}$ : Kepribadian merek berpengaruh positif signifikan terhadap kepercayaan merek.

Sabrina dan Siti (2011) menemukan pada penelitiannya bahwa komitmen merek berpengaruh positif signifikan terhadap loyalitas merek. Lee et al. (2007) dalam penelitiannya menemukan bahwa komitmen afektif dan komitmen kontinuitas secara signifikan berpengaruh positif terhadap loyalitas merek. Demir et al. (2013) dalam penelitiannya menemukan bahwa komitmen merek terbentuk oleh kepuasan pelanggan sehingga kemudian secara langsung mempengaruhi loyalitas merek konsumen tersebut. Turri et al. (2013) dalam penelitiannya meneliti hubungan komitemen afektif dengan salah satu bentuk loyalitas yaitu loyalitas pembelian, dan menghasilkan bahwa loyalitas pembelian merupakan keluaran dari komitmen afektif. Berg (2013) dalam penelitiannya mengenai perbedaan loyalitas produk utilitarian dan hedonik menemukan bahwa komitmen merek memiliki pengaruh positif terhadap loyalitas merek pada kedua katagori produk, namun pengaruh lebih kuat terhadap produk hedonik daripada terhadap produk utilitarian.

Terdapat gap dalam studi empiris yang semakin baru, dimana terdapat penelitian yang menemukan bahwa tidak sepenuhnya komitmen mempengaruhi loyalitas merek. Maheswari et al. (2014) adalah salah satu peneliti yang menemukan bahwa komitmen kontinuitas tidak secara signifikan mempengaruhi loyalitas merek. Penelitian ini sekali lagi menguji pengaruh komitmen merek secara utuh terhadap loyalitas merek.

$\mathrm{H}_{3}$ : Komitmen merek berpengaruh positif signifikan terhadap loyalitas merek.

Riana (2008) dan Ismail et al. (2012) dalam penelitian mereka menemukan bahwa kepercayaan merek berpengaruh positif terhadap loyalitas merek. Chandio et al. (2015) dalam penelitiannya juga menemukan hal yang sejalan, yaitu kepercayaan merek secara positif mempengaruhi loyalitas merek. Alhaddad (2015) dalam penelitiannya juga menemukan bahwa kepercayaan merek mempengaruhi kepercayaan loyalitas secara positif dan memediasi hubungan citra merek dengan loyalitas merek.

Terdapat gap dalam studi empiris karena ada beberapa penelitian yang menemukan bahwa kepercayaan merek tidak secara signifikan mendukung loyalitas merek. Kuikka dan Laukkanen (2012) dan Shirin dan Puth (2011) dalam penelitiannya juga menghipotesiskan bahwa kepercayaan merek merupakan menyebab yang signifikan bagi loyalitas merek, namun hasil penelitian tersebut adalah hipotesis tidak terdukung.

$\mathrm{H}_{4}$ : Kepercayaan merek berpengaruh positif signifikan terhadap loyalitas merek.

\section{METODE PENELITIAN}

Penelitian ini merupakan penelitian eksplanatori (explanatory research) yang dilakukan untuk menguji hipotesis (hypothesis testing) dengan pengujian hubungan diantara variabel yang diteliti (causal research). Dilihat dari waktu pelaksanaan, penelitian ini merupakan penelitian cross sectional karena dilakukan sekali pada kurun waktu tertentu. Unit analisis dalam penelitian ini adalah individual, masyarakat yang menggunakan produk kosmetik dan perawatan diri organik A merupakan produk perawatan diri organik. Subyek penelitian ini adalah konsumen produk kosmetik dan perawatan diri organik A. Sementara, obyek penelitian ini adalah kepribadian merek, komitmen dan kepercayaan merek, dan loyalitas merek yang dimiliki pelanggan terhadap merek produk kosmetik dan perawatan diri organik A.

Data kuantitatif yang digunakan dalam penelitian ini adalah data yang diperoleh dari jawaban kuesioner masing-masing responden yang telah diangkakan, sedangkan data kualitatif yang digunakan dalam penelitian ini adalah data mengenai responden, hasil penelitian sebelumnya yang telah dituliskan dalam bentuk kalimat dan grafik maupun tabel. Data bersumber dari sumber primer diperoleh dengan metode survei menggunakan kuesioner kepada responden, sedangkan data sekunder dalam penelitian merupakan hasil penelitian terkait yang digunakan sebagai dasar dalam penyusunan hipotesis dan justifikasi hasil penelitian ini.

Penelitian dilakukan pada 150 responden yang diambil dengan metode non-probability sampling, yaitu: metode pengambilan sampel yang tidak memberikan kesempatan yang sama pada seluruh anggota populasi untuk menjadi sampel penelitian (Indriantoro dan Supomo, 2012:114). Di dalamnya, teknik pengambilan sampel yang digunakan adalah purposive, dimana dalam menentukan sampel 
terdapat pertimbangan tertentu, yaitu: (1) responden berdomisili di Bali, (2) responden harus sudah pernah menggunakan produk kosmetik dan perawatan diri organik A, (3) responden pernah melakukan pembelian produk kosmetik dan perawatan diri organik A yang lebih dari satu kali, (4) pendidikan terakhir responden minimal SMA. Pengumpulan data dilakukan dengan survei dan instumen kuesioner. Metode pengumpulan data yang diterapkan pada penelitian ini adalah metode survei menggunakan instrumen kuesioner. Kuesioner itu sendiri berbentuk digital dan print out. Kuesioner digital dibuat dengan aplikasi Google docs dan disampaikan pada respondenyang ditemui peneliti secara langsung, melalui email dan aplikasi chatting untuk memberikan kemudahan dan kelengangan waktu bagi responden. Sementara print out diberikan pada responden yang lebih memilih print out.

Hipotesis penelitian diuji dengan menggunakan SEM (Structural Equation Modelling). Metode SEM memungkinkan pengujian serangkaian hubungan ketergantungan secara serempak yang akan membantu penggambaran arah dari kompleksitas manajerial dan isu-isu yang menyangkut perilaku konsumen (Maiga dan Jacob, 2005). Penelitian ini menggunakan pengujian validitas instrumen convergent berhubungan dengan prinsip bahwa indikator-indikator variabel berkorelasi tinggi. Sementara pengujian reliabilitas dalam penelitian ini, nilai reliabilitas dapat dilihat dari nilai cronbach's alpha (>0,5 = reliabel) dari hasil pengujian reliabilitas dengan menggunakan program SPSS, dan composite reliability.

Tabel 2. Ringkasan Rule of Thumb Uji Validitas dan Uji Reliabilitas

\begin{tabular}{lll}
\hline & Parameter & Rule of Thumb \\
\hline \multirow{2}{*}{ Validitas Konvergen } & Loading Factor & $>0,5$ \\
& Critical Ratio & $>(2 \times$ standard error $)$ \\
\hline \multirow{2}{*}{ Reliabilitas Konstruk } & Composite Reliability & $>0,7$ \\
& Croncbach's Alpha & $>0,7$ \\
\hline
\end{tabular}

Sumber: Ferdinand (2002:193); Latan (2012:48)

\section{HASIL DAN PEMBAHASAN}

Berdasarkan aspek jenis kelamin, sebesar $98,67 \%$ responden terdiri dari perempuan. Hal ini sejalan dengan jenis produk kosmetik dan perawatan diri organik Ayang merupakan produk kosmetik dan perawatan diri sehingga konsumennya cenderung adalah perempuan. Perempuan cenderung lebih memperhatikan penampilan dibandingkan dengan laki-laki.

Berdasarkan aspek usia, responden berpusat pada rentang $18-27$ tahun dan $28-37$ tahun yaitu sebesar $46 \%$ dan $44,67 \%$. Hal ini menunjukkan bahwa sebagian besar konsumen produk kosmetik dan perawatan diri organik Amerupakan masyarakat yang masih pada usia produktif, masih aktif untuk membangun, dan menunjukkan identitas dirinya.

Berdasarkan aspek pendidikan terakhir, dapat dilihat bahwa sebesar 57,33\% responden memiliki pendidikan terakhir S1. Hal ini sesuai dengan segmen pasar produk kosmetik dan perawatan diri organik Ayang merupakan masyarakat yang memiliki cukup pendidikan sehingga mereka lebih selektif dalam memilih produk yang digunakan, dan cukup memiliki pemahaman akan pentingnya kepedulian terhadap lingkungan.

Berdasarkan aspek pekerjaan, responden paling banyak bermata pencaharian sebagai pegawai swasta, yaitu sebesar 40\%. Hal ini berkaitan dengan kebutuhan sebagai pegawai swasta yang cenderung membutuhkan kreativitas sehingga tidak tertinggal persaingan di dunia kerja. Segmen masyarat ini dituntut untuk dapat menonjolkan nilai dan identitas dirinya agar menarik perhatian yang dibutuhkannya.

Pengujian hipotesis dilakukan dengan menggunakan teknik analisis SEM (Structural Equation Modeling) untuk melihat hubungan antar konstruk yang kompleks. Ini dikarenakan SEM dapat melakukan pengujian terhadap model pengukuran dan model struktural secara bersamaan. Pengujian terhadap model pengukuran dilakukan dengan melakukan ujivaliditas dan uji reliabilitas terhadap masing-masing indikator konstruk, yang ditunjukkan pada Tabel 3.

Tabel 3 menunjukkan indikator variabel-variabel penelitian ini beserta validitas konvergen dan reliabilitas konstruk penelitian. Berdasar data yang ditunjukkan pada tabel tersebut, dapat diketahui seberapa besar masing-masing indikator merefleksikan dimensi maupun variabelnya. Dimensi sincerity paling kuat direfleksikan oleh indikator konsisten menawarkan produk organik $\left(\mathrm{X}_{1.12}\right)$, namun paling lemah direfleksikan oleh indikator rendah hati dalam menyediakan produk organik $\left(\mathrm{X}_{1.11}\right)$. Dimensi excitement paling kuat direfleksikan oleh indikator semangat positif $\left(\mathrm{X}_{1.22}\right)$, namun paling lemah direfleksikan oleh indikator imajinatif $\left(\mathrm{X}_{1.33}\right)$. Dimensi competence paling kuat direfleksikan oleh indikator 
74 Matrik: Jurnal Manajemen, Strategi Bisnis dan Kewirausahaan Vol. 11, No. 1, Februari 2017

Tabel 3. Uji Validitas Konvergen dan Uji Reliabilitas Konstruk

\begin{tabular}{|c|c|c|}
\hline \multirow[t]{15}{*}{ Brand Personality } & Rendah hati menyediakan produk organik $\left(\mathrm{X}_{1.11}\right)$ & 0,838 \\
\hline & Konsisten menawarkan produk organik $\left(\mathrm{X}_{1.12}\right)$ & 0,955 \\
\hline & Senantiasa memberikan manfaat $\left(\mathrm{X}_{1.13}\right)$ & 0,935 \\
\hline & Membawa kesenangan bagi penggunanya $\left(\mathrm{X}_{1.14}\right)$ & 0,875 \\
\hline & Berani menonjol $\left(\mathrm{X}_{1.21}\right)$ & 0,646 \\
\hline & Semangat positif $\left(\mathrm{X}_{1.22}\right)$ & 0,805 \\
\hline & Imajinatif $\left(\mathrm{X}_{1.23}\right)$ & 0,613 \\
\hline & Up to date $\left(\mathrm{X}_{1.24}\right)$ & 0,667 \\
\hline & Dapat diandalkan $\left(\mathrm{X}_{1.31}\right)$ & 0,762 \\
\hline & $\operatorname{Pintar}\left(\mathrm{X}_{1.32}\right)$ & 0,580 \\
\hline & Kesuksesan $\left(\mathrm{X}_{1.33}\right)$ & 0,795 \\
\hline & Kelas atas $\left(\mathrm{X}_{1.41}\right)$ & 0.646 \\
\hline & Mempesona $\left(\mathrm{X}_{1.42}\right)$ & 0.832 \\
\hline & Bertahan di ruang terbuka $\left(\mathrm{X}_{1.51}\right)$ & 0.798 \\
\hline & Tahan lama $\left(\mathrm{X}_{1.52}\right)$ & 0.786 \\
\hline \multirow{3}{*}{$\begin{array}{l}\text { Brand } \\
\text { Commitment }\end{array}$} & Melibatkan diri $\left(\mathrm{Y}_{1.1}\right)$ & 0,783 \\
\hline & Waktu penggunaan lama $\left(\mathrm{Y}_{1.2}\right)$ & 0,884 \\
\hline & Berupaya menjaga hubungan $\left(\mathrm{Y}_{1.3}\right)$ & 0,600 \\
\hline \multirow[t]{4}{*}{ Brand Trust } & Kualitas produk $\left(\mathrm{Y}_{2.1}\right)$ & 0,796 \\
\hline & Manfaat sesuai harapan $\left(\mathrm{Y}_{2.2}\right)$ & 0,933 \\
\hline & Kualitas konsisten $\left(\mathrm{Y}_{2.3}\right)$ & 0,939 \\
\hline & Manfaat sesuai janji pada iklan $\left(\mathrm{Y}_{2.4}\right)$ & 0,676 \\
\hline \multirow[t]{8}{*}{ Brand Loyalty } & Memilih pada pembelian berikutnya $\left(\mathrm{Y}_{3.1}\right)$ & 0,764 \\
\hline & Pilihan terbaik $\left(\mathrm{Y}_{3.2}\right)$ & 0,701 \\
\hline & Merupakan pelanggan setia $\left(\mathrm{Y}_{3.3}\right)$ & 0,679 \\
\hline & Merekomendasikan $\left(\mathrm{Y}_{3.4}\right)$ & 0,793 \\
\hline & Pembelian ulang di masa depan $\left(\mathrm{Y}_{3.5}\right)$ & 0,734 \\
\hline & Pilihan terbaik $\left(\mathrm{Y}_{3.6}\right)$ & 0,602 \\
\hline & Mengungkapkan hal positif $\left(\mathrm{Y}_{3.7}\right)$ & 0,660 \\
\hline & Mendorong pembelian orang lain $\left(\mathrm{Y}_{3.8}\right)$ & 0,638 \\
\hline
\end{tabular}

Sumber: Hasil pengolahan data penelitian

kesuksesan $\left(\mathrm{X}_{1.33}\right)$, namun paling lemah direfleksikan oleh indikator pintar $\left(\mathrm{X}_{1.32}\right)$.Dimensi sophistication lebih kuat direfleksikan oleh indikator mempesona $\left(\mathrm{X}_{1.42}\right)$, namun lebih lemah direfleksikan oleh indikator kelas atas $\left(\mathrm{X}_{1.41}\right)$.Dimensi ruggedness lebih kuat direfleksikan oleh indikator bertahan di ruang terbuka $\left(X_{1.51}\right)$, namun lebih lemah direfleksikan oleh indikator tahan lama $\left(\mathrm{X}_{1.52}\right)$.

Variabel komitmen merek paling kuat direfleksikan oleh indikator waktu penggunaan lama $\left(\mathrm{Y}_{1.2}\right)$, namun paling lemah direfleksikan oleh indikator berupaya menjaga hubungan $\left(\mathrm{Y}_{1.3}\right)$. Variabel kepercayaan merek paling kuat direfleksikan oleh indikator kualitas yang konsisten
$\left(\mathrm{Y}_{2.3}\right)$, namun paling lemah direfleksikan oleh indikator manfaat sesuai janji pada iklan $\left(\mathrm{Y}_{2.4}\right)$. Variabel loyalitas merek paling kuat direfleksikan oleh indikator merekomendasikan $\left(\mathrm{Y}_{3.4}\right)$, namun paling lemah direfleksikan oleh indikator pilihan terbaik $\left(\mathrm{Y}_{3.6}\right)$.

Paparan di atas dan data yang ditunjukkan pada Tabel 3 menunjukkan bahwa data penelitian memenuhi syarat uji validitas dan uji reliabilitas, sehingga data layak digunakan untuk analisis terhadap model struktural, yang menunjukkan kekuatan estimasi antar variabel (Latan, 2012, p. 2). Gambar 3 berikut menunjukkan model struktural penelitian ini seperti berikut. 

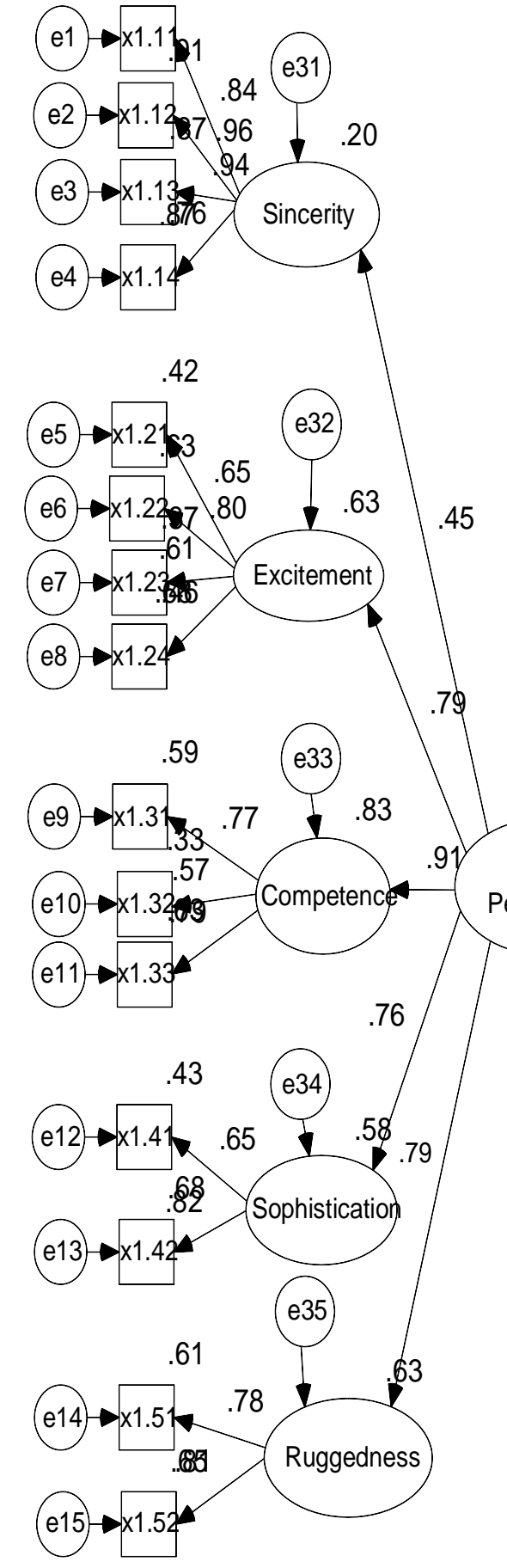

\section{Gambar 3. Measurement Model}

Tabel 4 menunjukkan bahwa Goodness of Fit model memenuhi syarat. Selain itu, asumsi SEM lainnya juga terpenuhi, seperti: 1) Evaluasi normalitas, nilai critical outlier data masih dalam rentang $\pm 2,58,2$ ) Evaluasi outlier, terdapat 6 data yang melebihi jarak Mahalanobis namun data yang tidak memenuhi evaluasi outlier dalam penelitian ini tetap digunakan karena membuang data-data tersebut sebaliknya berdampak negative, 3) Evaluasi multicollinearity dan singularity, nilai determinan of sample covariance matrix $>0$, sehingga dapat disimpulkan disimpulkan tidak ada multicollinearity dan singularity dalam data penelitian ini. 
Tabel 4. Kriteria Goodness of Fit

\begin{tabular}{llccc}
\hline No. & \multicolumn{1}{c}{ Kriteria } & Nilai Kritis & Nilai Model & Kesimpulan \\
\hline 1. & Chi-square & $\begin{array}{c}<43,39 \\
(\alpha=0,05 \mathrm{df}=396)\end{array}$ & 428,811 & Baik \\
2. & Probability & $\geq 0,05$ & 0,123 & Baik \\
3. & CMIN/DF & $\leq 2,00$ & 1,083 & Baik \\
4. & GFI & $\geq 0,90$ & 0,847 & Marginal \\
5. & TLI & $\geq 0,95$ & 0,986 & Baik \\
6. & CFI & $\geq 0,95$ & 0,987 & Baik \\
7. & RMSEA & $\leq 0,80$ & 0,024 & Baik \\
8. & AGFI & $\geq 0,90$ & 0,820 & Marginal \\
\hline
\end{tabular}

* Nilai chi-square tabel didapatkan dengan rumus chi-square menggunakan $\mathrm{p}=0,01 \mathrm{dan} \mathrm{df}=396$.

Sumber: Olahan Data Primer (2016)

Berikutnya dilakukan pengujian terhadap hubungan yang dibentuk dalam hipotesis-hipotesis penelitian, dengan melihat signifikan tidaknya hubungan tersebut melalui nilai critical ratio $(\mathrm{CR})$ pada Tabel 5. Hubungan dikatakan signifikan apabila nilai CR tidak sama dengan 0 , sehingga hubungan kausalitas yang signifikan dari variabel-variabel yang hubungannya digambarkan pada model penelitian ini dapat diterima.

Tabel 5. Regression Weight

\begin{tabular}{lclrrrrc}
\hline & & & Estimate & S.E. & C.R. & P & Label \\
\hline Brand commitment & $<---$ & Brand Personality & 1.098 & .181 & 6.056 & $* * *$ & par_27 \\
Brand trust & $<---$ & Brand Personality & .828 & .144 & 5.727 & $* * *$ & par_30 \\
Brand Loyalty & $<---$ & Brand commitment & .345 & .081 & 4.274 & $* * *$ & par_28 \\
Brand Loyalty & $<---$ & Brand trust & .400 & .086 & 4.648 & $* * *$ & par_29 \\
\hline
\end{tabular}

Sumber: Hasil pengolahan data penelitian, (2016

Tabel 6 menunjukkan pengaruh total antar variabel yang menggabungkan pengaruh langsung dan pengaruh tidak langsung.

Dapat dilihat pada Tabel 6 bahwa dari dua variabel yang memiliki hubungan langsung dengan kepribadian merek, hubungan yang lebih kuat terbentuk adalah hubungan dengan komitmen merek (sebesar 0,858), sedangkan loyalitas merek dipengaruhi oleh komitmen merek (sebesar 0,443) dan kepercayaan merek (sebesar 0,496). Selain itu, ada juga hubungan tidak langsung antara kepribadian merek terhadap loyalitas merek, yaitu sebesar 0,713.

\section{Pengaruh Kepribadian Merek Terhadap Komitmen Merek}

Hipotesis 1 penelitian ini yaitu: kepribadian merek berpengaruh positif signifikan terhadap komitmen merek, terdukung dengan C.R. $=6,056>$ 0 pada $\mathrm{p}<0,05$ dan pengaruh total sebesar 0,858 . Hal ini bermakna bahwa semakin kuat kepribadian merek produk kosmetik dan perawatan diri organik A yang dirasakan konsumen maka semakin tinggi komitmen konsumen tersebut terhadap merek produk kosmetik dan perawatan diri organik A.

Hasil penelitian ini sesuai dengan hasil penelitian Louis dan Lombart (2010) yang dilakukan di Kota
Prancis pada merek minuman bersoda Coca Cola. Penelitian Louis dan Lombart (2010) menggunakan indikator penelitian yang sama dengan penelitian ini yaitu dari penelitian Aaker (1997). Sabrina dan Siti (2011) melakukan duplikasi terhadap penelitian tersebut dan melakukan penelitian di Kota Surakarta tetap pada merek Coca Cola. Penelitian Sabrina dan Siti (2011) ini menemukan hasil yang sama dengan penelitian ini. Penelitian ini juga sesuai dengan hasil penelitian Ardestani dan Mahdi (2015) yang dilakukan pada industri olahan susu di Iran.

\section{Pengaruh Kepribadian Merek Terhadap Kepercayaan Merek}

Hipotesis 2 penelitian ini yaitu: kepribadian merek berpengauh positif signifikan terhadap kepercayaan merek, terdukung dengan C.R. $=5,727$ $>0$ pada $\mathrm{p}<0,05$ dan pengaruh total sebesar 0,670. Hal ini bermakna bahwa semakin kuat kepribadian merek produk kosmetik dan perawatan diri organik A yang dirasakan konsumen maka semakin tinggi kepercayaan konsumen tersebut terhadap merek produk kosmetik dan perawatan diri organik A.

Hasil penelitian ini sesuai dengan hasil penelitian Louis dan Lombart (2010) dan Sabrina dan Siti 
(2011). Selain itu, penelitian ini juga sesuai dengan penelitian Bouhlel et al. (2011) yang dilakukan di Afrika Utara.

\section{Pengaruh Komitmen Merek Terhadap Loyalitas Merek}

Hipotesis 3 penelitian ini yaitu: komitmen merek berpengauh positif signifikan terhadap loyalitas merek, terdukung dengan C.R. $=4,274>0$, pada $p$ $<0,05$ dan pengaruh total sebesar 0,443 . Hal ini bermakna bahwa semakin tinggi komitmen konsumen terhadap merek produk kosmetik dan perawatan diri organik A maka semakin tinggi pula loyalitas konsumen terhadap merek tersebut.

Hasil penelitian ini sesuai dengan hasil penelitian Turri et al. (2013) yang dilakukan di Amerika Serikat pada merek maupun artis yang beraktivitas melalui sosial media Facebook. Selain itu hasil penelitian ini juga sesuai dengan penelitian Demir et al. (2013) yang dilakukan di Kota Antalya, Turki.

\section{Pengaruh Kepercayaan Merek Terhadap Loyalitas Merek}

Hipotesis 4 penelitian ini yaitu: kepercayaan merek berpengauh positif signifikan terhadap loyalitas merek, terdukung dengan C.R. $=4,648>$ 0 , pada $\mathrm{p}<0,05$ dan pengaruh total sebesar 0,496. Hal ini bermakna bahwa semakin tinggi kepercayaan konsumen terhadap merek produk kosmetik dan perawatan diri organik A maka semakin tinggi pula loyalitas konsumen tersebut terhadap merek produk kosmetik dan perawatan diri organik A.

Hasil penelitian ini sesuai dengan hasil penelitian Lee et al. (2007) yang dilakukan di Taiwan pada empat merek ritel internasional, yaitu: Mc Donalds, Starbucks, Vieshow Cinemas, dan The Body Shop, dan hasil penelitian Ismail et al. (2012) yang dilakukan di Swedian pada bisnis ritel industri fashion. Lebih jauh hasil penelitian ini sejalan dengan hasil penelitian Chandio et al. (2015) yang dilakukan di Kota Karachi pada produk merek Hewlett Packard dan penelitian Alhaddad (2015)dilakukan di Swedia pada industri ritel.

\section{SIMPULAN DAN SARAN Simpulan}

Berdasarkan hasil penelitian dan pembahasan yang telah dilakukan, maka dapat diambil kesimpulan sebagai berikut: 1) Kepribadian merek berpengaruh positif signifikan terhadap komitmen merek pada produk kosmetik dan perawatan diri organik A. Hal ini berarti, semakin kuat kepribadian merek yang terbentuk pada benak konsumen maka semakin tinggi komitmen konsumen pada produk kosmetik dan perawatan diri organik Adi Kota Denpasar; 2) Kepribadian merek berpengaruh positif signifikan terhadap kepercayaan merek pada produk kosmetik dan perawatan diri organik A. Hal ini berarti, semakin kuat kepribadian merek yang terbentuk pada benak konsumen maka semakin tinggi pula kepercayaan konsumen pada produk kosmetik dan perawatan diri organik Adi Kota Denpasar; 3) Komitmen merek berpengaruh positif signifikan terhadap loyalitas merek pada produk kosmetik dan perawatan diri organik A. Hal ini berarti bahwa semakin tinggi komitmen konsumen pada merek produk kosmetik dan perawatan diri organik Amaka semakin tinggi pula loyalitas konsumen tersebut pada merek produk kosmetik dan perawatan diri organik A di Kota Denpasar dan 4) Kepercayaan merek berpengaruh positif signifikan terhadap loyalitas merek pada produk kosmetik dan perawatan diri organik A. Hal ini berarti bahwa semakin konsumen percaya pada merek produk kosmetik dan perawatan diri organik Amaka semakin loyal pula konsumen tersebut pada merek produk kosmetik dan perawatan diri organik A di Kota Denpasar.

\section{Saran}

Berdasarkan hasil penelitian dan pembahasan, untuk dapat meningkatkan loyalitas konsumen terhadap produk kosmetik dan perawatan diri organik merek Amaka dapat disarankan hal-hal sebagai berikut. 1) Selalu mengkomunikasikan manfaat kandungan organik dalam produk-produk merek produk kosmetik dan perawatan diri organik A; 2) Dengan lebih gencar beriklan untuk menunjukkan keaktifan produk kosmetik dan perawatan diri organik A dalam persaingan; 3) Memastikan konsumen menggunakan produk yang sesuai kebutuhannya dan kinerja produk tersebut dapat dirasakan secara riil oleh konsumen; 4) Meningkatkan kesan kelas atas merek produk kosmetik dan perawatan diri organik A. Hal ini dapat dilakukan dengan menggunakan brand endorser yang memiliki citra kelas atas; 5) Meningkatkan kesan tahan lama merek produk kosmetik dan perawatan diri organik A, hal ini dapat dilakukan dengan meningkatkan kuantitas per kemasan sehingga produk dapat digunakan untuk waktu yang lama atau memperpanjang masa berlaku produk, dan meningkatkan kualitas produk sehingga tidak mudah luntur akibat aktivitas konsumen; 6) Meningkatkan kesediaan konsumen untuk berupaya menjaga hubungannya dengan merek produk kosmetik dan perawatan diri organik A. Hal ini dapat dilakukan 
dengan memberikan feed back positif terhadap setiap kontribusi yang diberikan konsumen seperti manfaat, nilai tambah, maupun apresiasi; 7) Memastikan produk yang terdistribusi di seluruh cabang outlet produk kosmetik dan perawatan diri organik Amemiliki kualitas yang konsisten, untuk menghindari kekecewaan konsumen akibat pembelian produk di outlet yang berbeda; dan 8) Merek produk kosmetik dan perawatan diri organik Adapat meningkatkan loyalitas konsumen terhadap merek produk kosmetik dan perawatan diri organik A dengan menjadikan produk kosmetik dan perawatan diri organik A pilihan pertama dalam membeli produk perawatan pribadi organik dan menjadikan produk kosmetik dan perawatan diri organik A pilihan terbaik untuk produk perawatan pribadi organik.

\section{REFERENSI}

Aaker, J.L. 1997. Dimensions of Brand Personality. Journal of Marketing Research, Vol. 34 No. 3, pp. $347-356$.

Alexander, D. 2014. Analisis Pengaruh Citra Merek dan Kepercayaan Merek terhadap Loyalitas Merek Ades PT. Ades Afindo Putra Setia. Journal Manajemen Petra, Vol. 2, No. 1.

Alhaddad, A. 2015. A Structural Model of The Relationship Between Brand Image, Brand Trust, and Brand Loyalty. International Journal of Management Research and Review, Vol. 5, No. 1, pp. 137 - 144.

Ambroise, L., Ben Sliman, S., Bourgeat, P., De Barnier, V., Ferrandi, J-M., Merunka, D., Roehrich, G. and Valette-Florence, P. 2005. The Impact of Brand Personality on Attitude and Commitment towards the Brand, CD-ROM, Proceedings of the $32^{\text {nd }}$ International Research Seminar in Marketing, Marketing Communications and Consumer Behavior, La Londe les Maures, France, June.

Ardestani, A.S. and Mahdi A. 2015. Relationship between Brand Personality, Attitude and Commitment to Brand Name (Case Study: Dairy Industry of Iran). European Online Journal of Natural and Social Science, Vol. 4, No. 1, pp. 899 - 905.

Aydin, G., Aybeniz A.A.R., and Cagatan T. 2014. The Role of Brand Trust on Parents' Purchase Intentions of Baby-care Products. Doðup Üniversitesi Dergisi, Vol. 15, No. 2, pp $165-180$.

Berg, G. van den 2013. Brand Loyalty: Is There a Difference in the Creation of Consumers' Brand Loyalty between Utilitarian Products and
Hedonic Products? Thesis, Msc Business Studies, University of Amsterdam, Amsterdam. Bouhlel, O., Nabil M., Doraf H., and Ichrak B.S. 2011. Brand Personality's Influence on the Purchase Intention: A Mobile Marketing Case. International Journal of Business and Management, Vol. 6, No. 9, pp. 210 - 227.

Chandio, Z.U., M. A. Qureshi, and S. Ahmed. 2015. Brand Trust, Customer Satisfaction and Brand Loyalty - A Cross Examination. Journal of Business Strategies, Vo. 9, No. 1, pp. 63 - 82. Demir, M.O., N. Yuzbasioglu, and M. Bezirci. 2013. A Review of The Relationship between Brand Loyalty, Customer Satisfaction, and Commitment using Structural Equation Model within The Internal Control Process. African Journal of Business Management, Vol. 7, No. 13, pp. 1067-1078.

Ferrinadewi, E. 2008. Merek dan Psikologi Konsumen. Cetakan pertama. Yogyakarat: Graha Ilmu.

Freling, T. H., and Lukas P. F. 2005. An Examination of Brand Personality Through Methodological Triangulation. Journal of Brand Management, Vol. 13, No. 2, 148-62.

Goldberg, L. R. 1992. The Development of Markers of the Big-Five Factor Structure. Psychological Assessment, Vol. 4, No. 1, pp. $26-42$.

Grohmann, B. 2009. Gender dimensions of brand personality. Journal of Marketing Research, Vol. 46, No. 1, pp. 105 - 119.

Guse, von K. S. 2011. Brand Personality and Consumer-brand Relationship as Elements of Successful Brand Management. Bamberg: University of Bamberg Press.

Indriantoro, Nur, dan B. Supomo. 2012. Metodologi Penelitian Bisnis. Edisi Pertama. Yogyakarta: Fakultas Ekonomika \& Bisnis UGM.

Ismail R., C.L. Boye, and A. Muth. 2012. Customer Brand Relationship: An Empirical Study of Customer's Perception of Brand Experience, Bran Satisfaction, Brand Trust and How They Affect Brand Loyalty, Thesis, School of Business and Economics, Linnaeus University, Swedia.

Kuikka, A. and T. Laukkanen. 2012. Brand Loyalty and the Role of Hedonic Value. Journal of Product \& Brand Management, Vol. 21, No. 7, pp. $529-537$.

Latan, H. 2012. Structural Equation Modeling: Konsep dan Aplikasi Menggunakan Program LISREL 8.80. Bandung: Penerbit Alfabeta. 
Lee, H.J. and Myung S.K. 2013. The Effect of Brand Personality on Brand Relationship, Attitude and Purchase Intention with a Focus on Brand Community. Journal of Academy of Marketing Studies Journal, Vol. 17, No. 2.

Lee, K.Y., H.L. Huang, and Y.C. Hsu. 2007. Trust, Satisfaction and Commitment On Loyalty to International Retail Service Brands. Asia Pasific Management Review, Vol. 12, No. 3, pp. $161-169$.

Li, N., Andrew R. and Nigel C. 2013. Luxury Brand Commitment: A Study of Chinese Consumers. Marketing Intelligence and Planning, Vol.32, No. 7, pp. 769 - 793.

Listiani, N. 2013. Pengaruh Kepuasan pada Merek dan Komitmen terhadap Niat Membeli Kembali. BENEFIT Jurnal Manajemen dan Bisnis, Vol. 17, No. 1, hal. 66 - 74 .

Louis, D. and Cindy L. 2010. Impact of Brand Personality on Three Major Relational Consequences (Trust, Attachment, and Commitment to the Brand), Journal of Product \& Brand Management, Vol. 19, No. 2, pp. 114-130.

Maheswari, V., G. Lodorfors, and S. Jacobsen. 2014. Determinants of Brand Loyalty: A Study of the Experience-Commitment-Loyalty Constructs. International Journal of Business Administration, Vol. 5, No. 6, pp. 13 - 23.

Maiga, S. Adam dan J. A. Fred. 2005. Antecedents and Consequences of Quality Performance. Behavioral Research in Accounting.

Paramita, N.D. dan N. N. Kerti Yasa. 2015. Sikap dalam Memediasi Hubungan Kesadaran Lingkungan dengan Niat Beli Produk Kosmetik Ramah Lingkungan. Journal Manajemen dan Kewirausahaan, Vol. 17, No. 2, hal. 177 - 185.
Plummer, J. T. 2000. How Personality Makes a Difference. Journal of Advertising Research, Vol. 40, No. 6, pp. 79 - 83.

Riana, Gede. 2008.Pengaruh Trust In A Brand Terhadap Brand Loyalty Pada Konsumen Air Minum Aqua Di Kota Denpasar. Buletin Studi Ekonomi Vol.13 No.2

Rizwan, M., U. Mahmood, H. Siddiqui, A. Tahir. 2014. An Empirical Study about Green Purchase Intentions. Journal of Sociological Research, Vol. 5, No. 1, pp. $290-305$.

Sabrina, Y.A., dan Siti K. 2011. Pengaruh Brand Personality pada Brand Trust, Brand Attachment, Brand Commitment, dan Brand Loyalty. Jurnal Bisnis dan Ekonomi (JBE), Vol. 18, No. 2, hal. 114 - 125.

Schiffman, L. dan L. Kanuk. 2008. Perilaku Konsumen, Edisi Ketujuh. Indonesia: PT. Macanan Jaya Cemerlang.

Shirin, A. and G. Puth. 2011. Customer Satisfaction, Brand Trust and Variety Seeking as Determinants of Brand Loyalty. African Journal of Business Management, Vol. 5, No. 30, pp. 11899-11915.

topbrand-awards.com (diakses pada 22 Agustus 2016)

Turri, A.M., K.H. Smith, E. Kemp. 2013. Developing Affective Brand Commitment Through Social Media. Journal of Electronic Commerce Research, Vol. 14, No. 3, pp. 201 - 214.

Waskito, J. 2015. Upaya Meningkatkan Niat Pembelian Produk Ramah Lingkungan Melalui Nilai, Risiko, dan Kepercayaan Terhadap Produk Hijau. Etikonomi, Vol. 14, No. 1, hal. 1 - 16.

Yasin, M. and Amjad S. 2013. Brand Love: Mediating Role in Purchase Intention and Word-of-Mouth. Journal of Business and Management, Vol. 7, No. 2, pp. $101-109$. 